\title{
$50 \mathrm{Cr}-\mathrm{Ni}$ 合金の熱間加工性についで
}

\author{
石川英次郎 ${ }^{* *}$, 水野 博司 ${ }^{* *}$, 山崎 光雄 ${ }^{* *}$, 猪狩 卓 ${ }^{* *}$
}

\section{On the Hot Workability of 50Cr-Ni Alloys}

\section{Eijiro Ishikawa, Hiroshi Mizuno, Mitsuo Yamazaki and Takashi Ikari}

\begin{abstract}
Synopsis
Relation between hot workability and alloying element in $50 \mathrm{Cr}-\mathrm{Ni}$ alloys was studied.

Hot workability was estimated by the hot torsion and hot upsetting tests. The results abtained from the study were as follows:

1) Hot workability has been considerably improved by addtion of $\mathrm{Ti}$ or $\mathrm{Zr}$ and more addtion of $\mathrm{Zr}$ content reduces hot workability.

2) Hot workability has been improved by vacuum induction melted.

3) In a several hot corrosion tests, $50 \mathrm{Cr}-\mathrm{Ni}$ alloy containing $\mathrm{Ti}, \mathrm{Zr}$ or $\mathrm{Nb}$ showed behavior similar to that of $50 \mathrm{Cr}-50 \mathrm{Ni}$ alloy.
\end{abstract}

\section{1. まえがき}

ボイラ過熱管のスペーサー支持具などのように重油 その他の燃焼灰によって生ずる厳しい高温腐食環境に 対しては $50 \mathrm{Cr}-\mathrm{Ni}$ 合金が優れた耐食性を示すことが よく知られており1，2)，一般に鋳造合金として用い られている。しかし，熱間加工が極めて困難なので使 用範囲に限界があり，加工改善によるパイプ，ボル ト，線などの実用化が望まれている。したがってその 加工性向上を目的に Ti， Nb，Zr，REなどの影響, 均熱処理，鋳造組織および真空溶解などについて定性 的に実験調查を行ったので，その結果について報告す る。

昭和51年10月11日 受付

*昭和 50 年 4 月鉄鋼協会春期講演大会にて発表

**大同特殊銅的技術部

${ }^{* * *}$ 大同特殊鋼株研究開発本部中央研究所川崎研究室

\section{2. 供試材および実験方法}

50Cr-50Ni合金を基本型とし，これに $\mathrm{Ti}, \mathrm{Nb}, \mathrm{Zr}$ およびREを添加したものについて，高周波誘導炬に より $7 \mathrm{~kg}$ 鋼塊を溶製した。一部真空溶解により $5 \mathrm{~kg}$ 鋼 塊と一方向频固により $2 \mathrm{~kg}$ 鋼塊を溶製し供試材とし た。熱間加工性の評価は垂鍾落下試験とねじり試験に より行った。

Table 1 は，大気溶解した $7 \mathrm{~kg}$ 鋼塊の化学成分を示 す。試料 No.1 は, 50Cr-50Ni 標準材であり, No. 2 ～7はTi，No.8〜13はNb，No.14〜19は Zr を単独添 加したものである。No. 20〜28はこれら元素を複合添 加したものであり，それでれについて REを源加した ものと無添加のものにわけ，その影響をみた。

Fig. 1 は試験片の张取状態を示したものである。 まず押湯部分を除去し，80〜85mmをねじり試片に， 下部を落重試片採取にあてた。横断面図に示すごとく 鋼塊を 8 分割し，それぞれ中心から柱状晶に垂直にね じり試片を落重試片は水平に播取した。試験片は札じ 
Table 1. Chemical compositions of specimens.

\begin{tabular}{c|c|c|c|c|c|c|c|c|c|c|c}
\hline No. & $\mathrm{C}$ & $\mathrm{Si}$ & $\mathrm{Mn}$ & $\mathrm{P}$ & $\mathrm{S}$ & $\mathrm{Ni}$ & $\mathrm{Cr}$ & $\mathrm{Ti}$ & $\mathrm{Nb}$ & $\mathrm{Zr}$ & $\mathrm{RE}$ \\
\hline 1 & 0.070 & 0.33 & 0.58 & 0.004 & 0.002 & $\mathrm{Bal}$ & 48.93 & & & & \\
\hline 2 & 0.125 & 0.37 & 0.58 & 0.006 & 0.006 & $\prime \prime$ & 50.81 & 0.47 & & & \\
\hline 3 & 0.123 & 0.38 & 0.57 & 0.004 & 0.004 & $\prime \prime$ & 49.97 & 1.06 & & & \\
\hline 4 & 0.128 & 0.37 & 0.57 & 0.004 & 0.006 & $\prime$ & 50.91 & 2.55 & & & \\
\hline 5 & 0.122 & 0.41 & 0.57 & 0.005 & 0.005 & $\prime \prime$ & 50.09 & 0.15 & & & 0.07 \\
\hline 6 & 0.089 & 0.38 & 0.58 & 0.004 & 0.004 & $\prime$ & 51.65 & 1.12 & & & 0.10 \\
\hline 7 & 0.114 & 0.36 & 0.57 & 0.004 & 0.004 & $\prime$ & 51.35 & 2.48 & & & 0.06 \\
\hline 8 & 0.111 & 0.35 & 0.59 & 0.005 & 0.005 & $\prime \prime$ & 50.37 & & 0.49 & & \\
\hline 9 & 0.109 & 0.35 & 0.56 & 0.006 & 0.006 & $\prime \prime$ & 50.58 & & 1.42 & & \\
\hline 10 & 0.097 & 0.33 & 0.58 & 0.009 & 0.006 & $\prime$ & 51.29 & & 2.86 & & \\
\hline 11 & 0.098 & 0.33 & 0.57 & 0.005 & 0.005 & $\prime \prime$ & 50.00 & & 0.74 & & 0.07 \\
\hline 12 & 0.104 & 0.34 & 0.53 & 0.007 & 0.007 & $\prime$ & 50.59 & & 1.45 & & tr \\
\hline 13 & 0.098 & 0.36 & 0.59 & 0.009 & 0.005 & $\prime$ & 50.06 & & 2.88 & & 0.14 \\
\hline 14 & 0.108 & 0.35 & 0.58 & 0.004 & 0.008 & $\prime \prime$ & 50.03 & & & 0.16 & \\
\hline 15 & 0.101 & 0.34 & 0.59 & 0.007 & 0.004 & $\prime \prime$ & 50.10 & & & 0.92 & \\
\hline 16 & 0.113 & 0.37 & 0.66 & 0.009 & 0.006 & $\prime \prime$ & 49.70 & & & 1.96 & \\
\hline 17 & 0.121 & 0.33 & 0.57 & 0.005 & 0.004 & $\prime \prime$ & 49.75 & & & 0.41 & 0.17 \\
\hline 18 & 0.115 & 0.37 & 0.59 & 0.007 & 0.004 & $\prime$ & 50.10 & & & 0.93 & 0.05 \\
\hline 19 & 0.108 & 0.36 & 0.58 & 0.008 & 0.006 & $\prime \prime$ & 50.17 & & & 2.32 & 0.12 \\
\hline 20 & 0.169 & 0.34 & 0.58 & 0.007 & 0.007 & $\prime \prime$ & 50.95 & 0.04 & 1.54 & 0.15 & \\
\hline 21 & 0.116 & 0.37 & 0.58 & 0.010 & 0.006 & $\prime \prime$ & 50.05 & 0.45 & 1.56 & 0.90 & \\
\hline 22 & 0.087 & 0.36 & 0.61 & 0.010 & 0.005 & $\prime \prime$ & 49.50 & 0.33 & 1.44 & 1.84 & \\
\hline 23 & 0.096 & 0.40 & 0.57 & 0.007 & 0.004 & $\prime \prime$ & 50.92 & 0.31 & 1.52 & 0.16 & 0.13 \\
\hline 24 & 0.090 & 0.35 & 0.58 & 0.010 & 0.002 & $\prime \prime$ & 49.81 & 0.43 & 1.56 & 1.02 & 0.26 \\
\hline 25 & 0.084 & 0.35 & 0.58 & 0.012 & 0.007 & $\prime$ & 49.38 & 0.39 & 1.59 & 1.50 & tr \\
\hline 26 & 0.090 & 0.36 & 0.59 & 0.005 & 0.005 & $\prime \prime$ & 50.40 & 0.42 & 0.75 & & 0.13 \\
\hline 27 & 0.102 & 0.34 & 0.58 & 0.009 & 0.004 & $\prime \prime$ & 51.05 & 0.41 & 1.46 & & 0.14 \\
\hline 28 & 0.103 & 0.35 & 0.57 & 0.007 & 0.004 & $\prime \prime$ & 50.79 & 0.13 & 2.99 & & 0.13 \\
\hline
\end{tabular}

りが平行部径 $8 \mathrm{~mm} \phi$, 長さ $30 \mathrm{~mm}$, 落重試片は $10 \mathrm{~mm} \phi$ $\times 12 \mathrm{~mm}$ とした。鋼塊の横断面マクロ組織の一例を同 時に示した。

\section{3. 実 験 結 果}

\section{1 予備 実験結果}

3. 1. 1 RE 添加および均熱処理の影慗 50Cr-Ni 合金は熱間加工の困難な材料であるか，一
般的に加工性改善に RE が効果があるとされているの で，予備実験としてRE 添加の影響を調べた。Fig. 2 は30kgの重䤵を $1 \mathrm{~m} の$ 高さからフリー落下した場合の 結果で，非常に定性的な結果であるか， RE 添加によ り加工温度範囲を拡大する結果が得られだ。つぎ均 熱処理も加工性改善に有効な方法であるので， $\mathrm{Ti}$, $\mathrm{Nb}$ および $0.3 \% \mathrm{RE}$ を添加した材料について均秇処理 温度の影響を調べた。Fig. 3 に示すごとく $\mathrm{Ti}+\mathrm{Nb}$ 量 

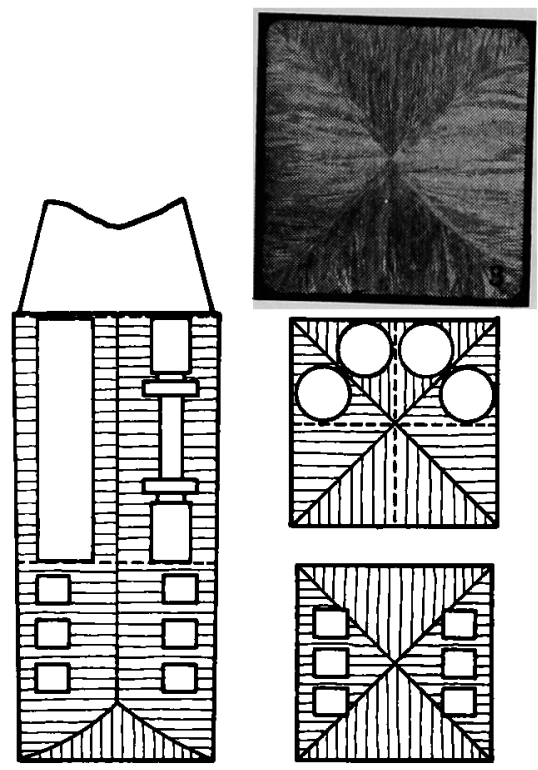

Torsion test piece : Dia. $8 \mathrm{~mm}$

: Gauge length $30 \mathrm{~mm}$

Upsetting test piece : Dia. $10 \times 12 \mathrm{~mm}$

Fig. 1. Sampling position of specimen

\begin{tabular}{c|c|c|c|c|c|c|r}
\hline $\begin{array}{c}\text { Speci- } \\
\text { men }\end{array}$ & $\mathrm{C}$ & $\mathrm{Si}$ & $\mathrm{Mn}$ & $\mathrm{Ni}$ & $\mathrm{Cr}$ & $\mathrm{Ti}$ & $\mathrm{RE}$ \\
\hline $\mathrm{A}$ & 0.11 & 1.13 & 0.41 & $\mathrm{Bal}$ & 48.40 & 0.28 & - \\
$\mathrm{B}$ & 0.16 & 0.72 & 0.32 & $\mathrm{Bal}$ & 46.25 & 0.04 & 0.2 \\
$\mathrm{C}$ & 0.13 & 0.96 & 0.39 & $\mathrm{Bal}$ & 49.05 & 0.08 & 0.4 \\
\hline
\end{tabular}

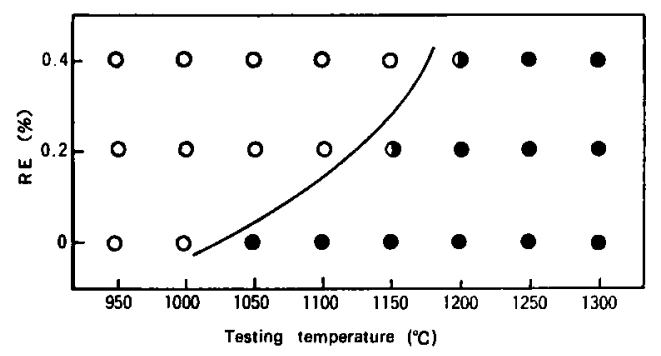

Fig. 2. Effect of RE addition on the hot workability of $50 \mathrm{Cr}-\mathrm{Ni}$ alloy.

が 1\%程度の場合は鍛造のままでも割れの発生はない が， $1.6 \%$ 以上で割れが発生する。加熱保持時間は $5 \mathrm{hr}$ であるが $1100^{\circ} \mathrm{C}$ までの均熱温度では効果が少な く1200Cでかなりの效果が認められた。

\subsection{2 筑固組識の影慗}

Fig. 4 は凝固組織と加工性との関連をみるべく, 一方向凝固にて溶製した銿塊による落重試験結果であ

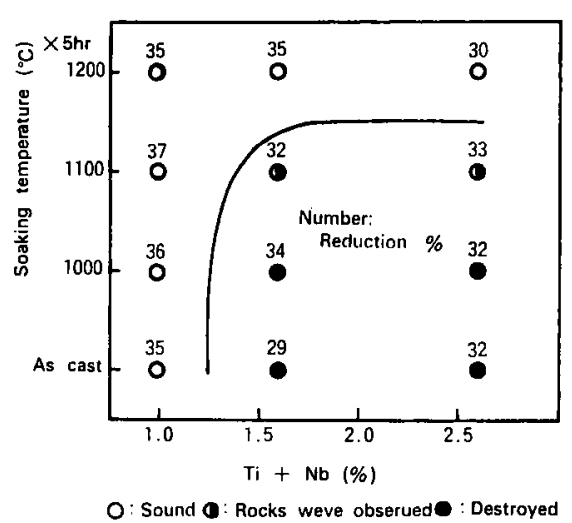

Fig. 3. Effect of $\mathrm{Ti}+\mathrm{Nb}$ and soaking temperature on the hot-ductility (Testing temp. : $1050^{\circ} \mathrm{C}$ ).

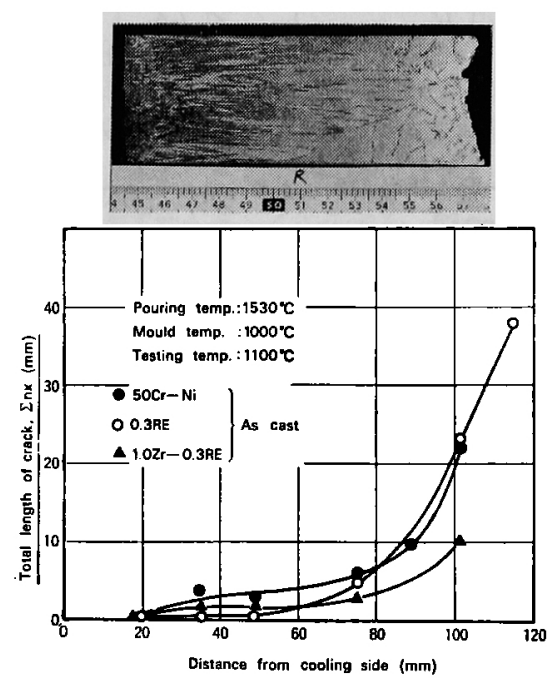

Fig. 4. Effect of solidification structure on the hot workability.

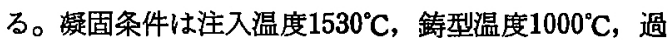
熱度 $\Delta \mathrm{T}=200^{\circ} \mathrm{C} て ゙ ， マ ク ロ$ 組織から柱状晶十等軸晶で ある。落重試験の評価はきず総長で示したが，標準材 である50Cr-50Ni 合金およびRE 添加材は冷却端より の距離 $80 \mathrm{~mm}$ 以上，すなわち等軸晶領域で急激に割れ 発生傾向が大となっている。Zr-RE 添加材も類似の 傾向を示すが，若干良好な結果を示した。

つぎに，おのおの一定の条件で柱状晶および等軸晶 の鋼塊を溶製した。柱状晶溶製条件は鋳込温度 1530 ${ }^{\circ} \mathrm{C}$, 鋳型温度 $1200^{\circ} \mathrm{C}$, 過熱度 $\Delta \mathrm{T}=200^{\circ} \mathrm{C}$ である。結果 はFig. 5 に示すごとくであり，柱状晶の場合標準材 であっても割れの発生は皆無であった。鋳込温度 1370 ${ }^{\circ} \mathrm{C}$, 型温度 $1000^{\circ} \mathrm{C}$, 過熱度 $\Delta \mathrm{T}=40^{\circ} \mathrm{C}$ での等軸晶の 場合はきず発生傾向はかなり大きい。0.3\%RE添加， 


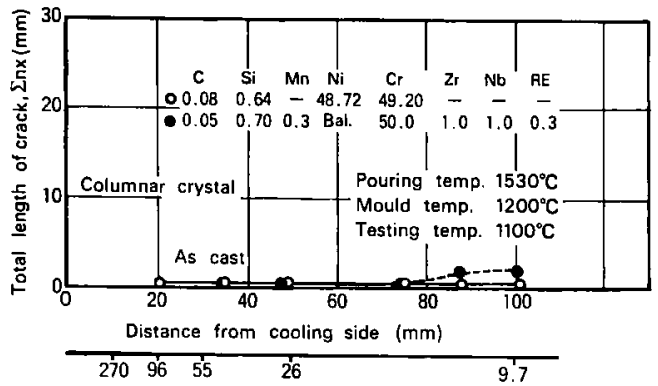

Mean cooling velocity $\left({ }^{\circ} \mathrm{C} / \mathrm{min}\right)$

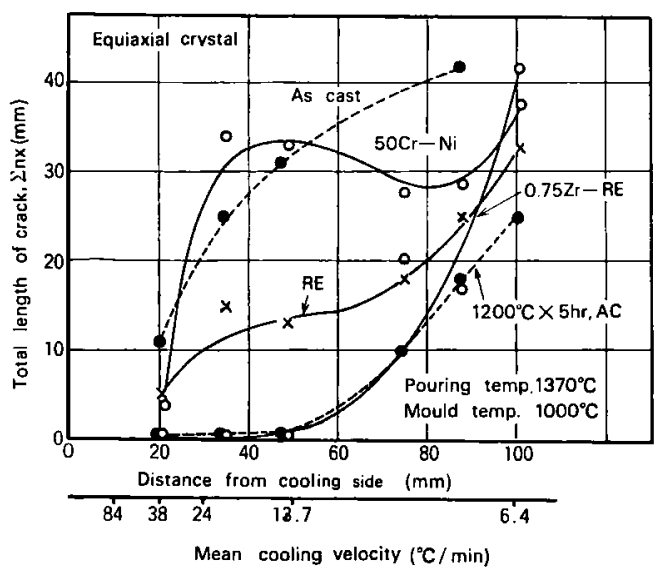

Fig. 5. Effect of solidification structure on the hot workability.

Table 2. results of torsion test. $\left(1100^{\circ} \mathrm{C}\right.$ Test)

\begin{tabular}{|c|c|c|c|c|}
\hline \multirow{2}{*}{ No. } & \multirow{2}{*}{ Type } & \multirow{2}{*}{ Structure } & \multicolumn{2}{|c|}{ As cast } \\
\hline & & & $\begin{array}{l}\text { Torque } \\
(\mathrm{kg} \cdot \mathrm{m})\end{array}$ & $\begin{array}{l}\text { Torsion } \\
\text { number }\end{array}$ \\
\hline \multirow{2}{*}{1} & \multirow{2}{*}{$50 \mathrm{Cr}-\mathrm{Ni}$} & A & 200 & 1.2 \\
\hline & & B & 155 & 0.2 \\
\hline \multirow{2}{*}{2} & \multirow{2}{*}{ 0. 3-RE } & A & 209 & 1.2 \\
\hline & & B & 164 & 1.3 \\
\hline \multirow{2}{*}{3} & \multirow{2}{*}{ 1. $0 Z \mathrm{Zr}-\mathrm{RE}$} & A & 180 & 3.0 \\
\hline & & B & 193 & 1.0 \\
\hline \multirow{2}{*}{4} & \multirow{2}{*}{$1 Z r-1 N b-R E$} & A & 202 & 1.7 \\
\hline & & B & 185 & 0.7 \\
\hline
\end{tabular}

かなり良好な秥果を示すが，等軸晶はきずの発生が多

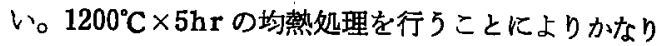
の加工性改善がなされたが，いずれる冷却速度が遅い 場合はまだ不十分である。Table 2 に示すねじり試験 結果でもほほ同様の結果が得られたが，等軸晶に比較 し柱状晶の方が良好な熱間加工性を示すことが明らか となった。

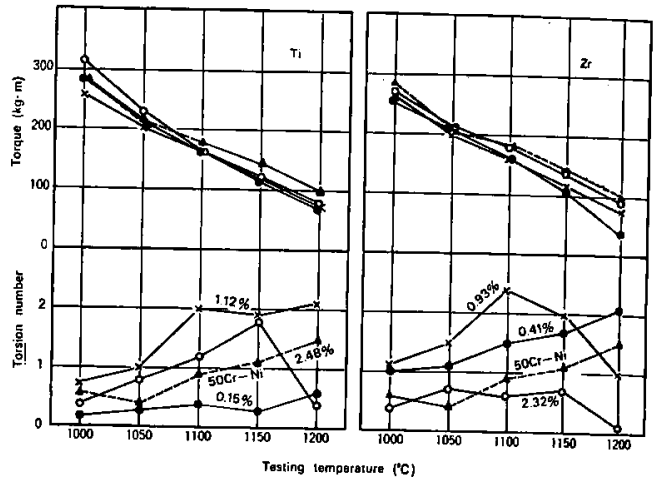

Fig. 6. Relation between torsion number, torque and testing temperature.

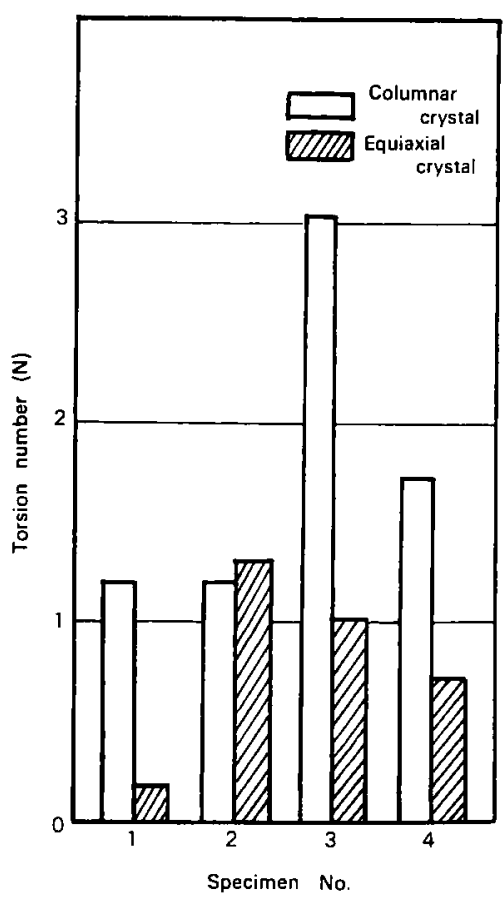

A Columnor crystal : Pouring temp. $1530^{\circ} \mathrm{C}$, Mould temp. $1200^{\circ} \mathrm{C}$

B Equiaxial crystal : Pouring temp. $1370^{\circ} \mathrm{C}$, Mould temp. $1000^{\circ} \mathrm{C}$

さらにはZr-RE添加でその改善効果は顕著となる。

Fig. 5 は強度改善に有効な $\mathrm{Nb} Z \mathrm{r}-\mathrm{RE}$ と複合添 加した場合の結果である。この場合でも柱状晶では

\section{2 添加元素の影望}

\subsection{1 熱間ねしり試験}

一般に鉛造加工性の評価には，ねじり試験は適当で 


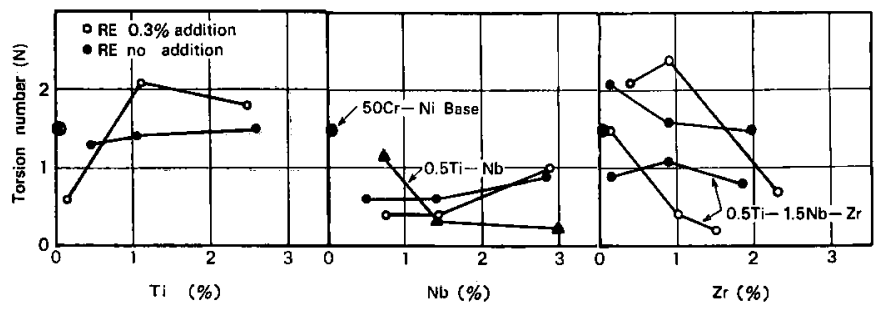

Fig. 7. Relation between hot-ductility and alloying elements.

ないといわれているが，落重試験は定性的であるの で, 変形能の定量的評洒の一環としてねじり試験を行 った。Fig. 6 は $50 \mathrm{Cr}-50 \mathrm{Ni}$ 標準材に対して改善效果 のあった Ti，Zr の結果を示したものである。点線で 示したものが標準材の結果であるが，試験温度の上年 とともにねじり回数も増加し， $1200^{\circ} \mathrm{C}$ で最高 1.5 回を 示した。これに対しTi 添加材では $1 \% \mathrm{Ti}-\mathrm{RE}$ 以上で, 標準材を凌駕しているが，2.5\% Ti-REと多くなると $1 \% \mathrm{Ti}$ の場合より低下する。Zr の場合は0.4，0.9\% 之添加量とともに向上するが，2.3\%Zr では急激に劣 化する。とくに $0.9 \%$ \%のるのは高温側での低下が 著しい。

Fig. 7 はFig. 6 で示したごとき試験結果から各合 金元素量と変形能, 寸なわち最高ねじり回数との関係 を示したすのである。の印は，標準材の結果であり黒 丸（O）はRE 無添加，白丸（O）はそれぞれ 0.3\%

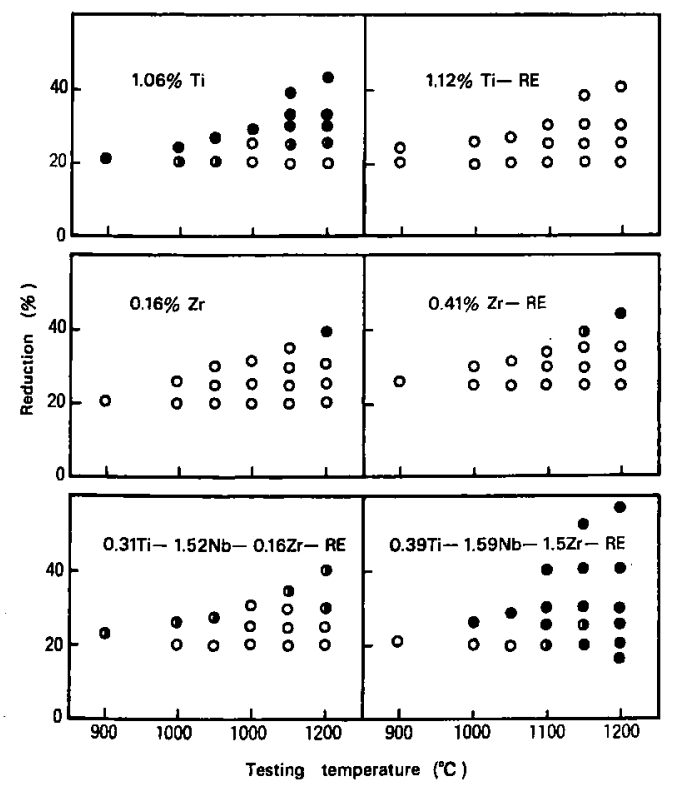

Fig. 8. Effect of alloying elements on the hot upsetting tests.
$\mathrm{RE}$ を添加したものの結果である。図から明らかなご とく Ti，Zr の効果が明らかである。

\section{2 .2 落 重 試 験}

試験温度 $900 \sim 1200^{\circ} \mathrm{C}$ で加工率を変えた場合の割れ の有無によって加工性を評価した。結果を Fig. 8 に 示す。D印は発生したきずの総長さが $5 \mathrm{~mm}$ 以下の場 合を表わす。Ti，ZrはRE添加の影響を，Ti-Nb-Zr$\mathrm{RE}$ 複合添加の場合は $Z \mathbf{r}$ 量の影響を示したものであ る。TiはRE 添加により顕著な改善効果があり，Zrの 場合は影響が少ない。複合添加材では Zr が多くなる とかえって加工性が著しく劣化する。Fig. 9 は割れ の発生しない限界加工率を標準材と比較したすのであ る。太線で示したのが50Cr-50Ni標準材の值で，Ti， ZrおよびTi-Nb 複合添加材がREとの関連において標 準材より良好な結果を示した。

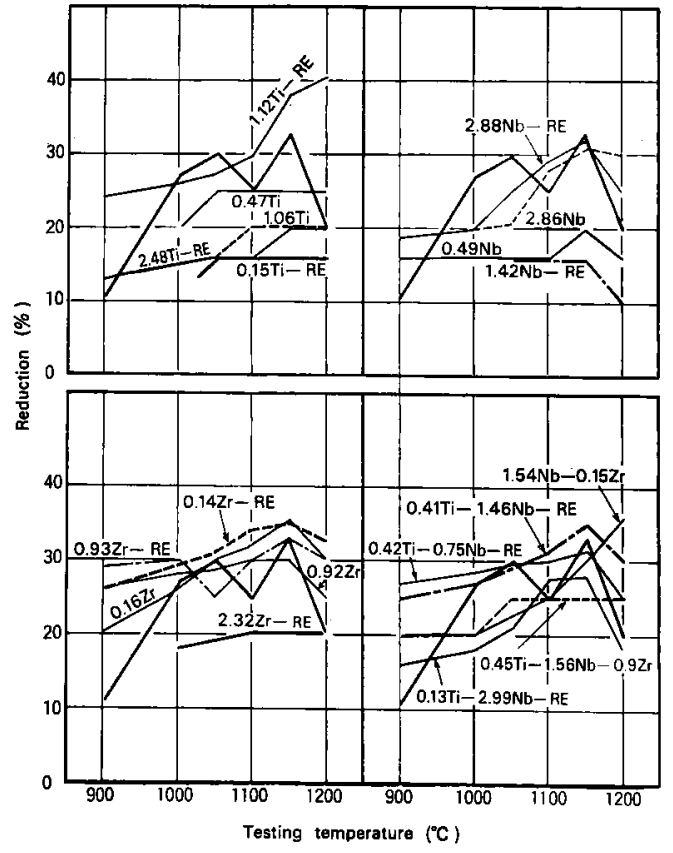

Fig. 9. Effect of alloying elements on the hot upsetting tests. 
つぎに, 落重試験における変形量から平均変形抵抗 を求め,合金元素との関連において示したのがFig. 10 である。䓡間加工を行 5 場合変形能とともに変形抵抗

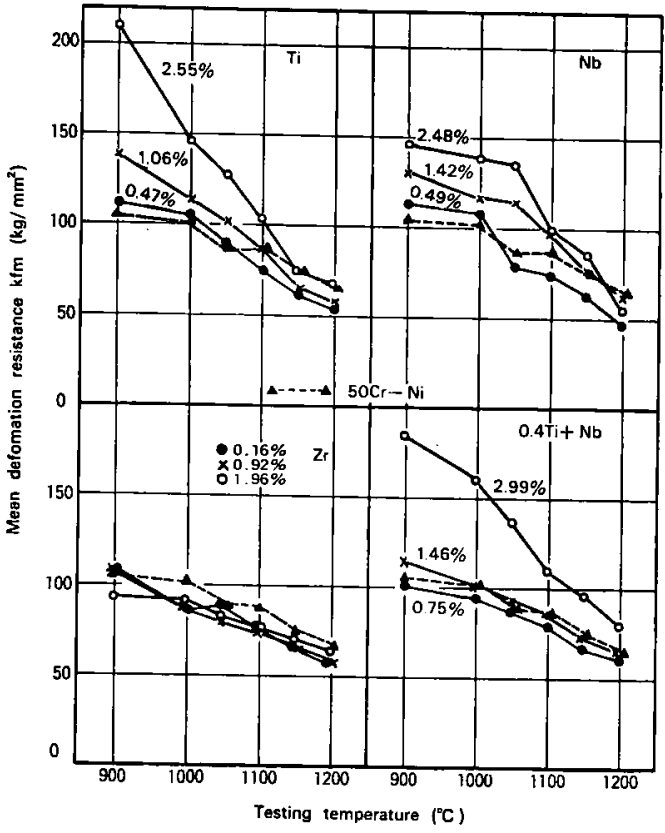

Fig. 10. Effect of alloying elements on the mean deformation resistance.

も重要な因子として考えなければならない。図から明 らかなごとく $\mathrm{Ti}, \mathrm{Nb}$ は添加量に比例し変形抵抗か増 大するが，Zr は変化が少なく，標準材と比較しても 若干低い。これらの点からも50Cr-Ni合金における熱
間加工性向上に対してZr は有用な元素と考えられる。 Fig.11はそれぞれの試料の $\alpha$ 相と $\gamma$ 相の硬さをマィ クロビッカースにて測定した結果である。変形抵抗の

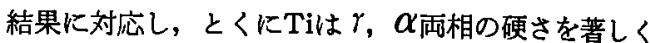
㙕加させる傾向にある。

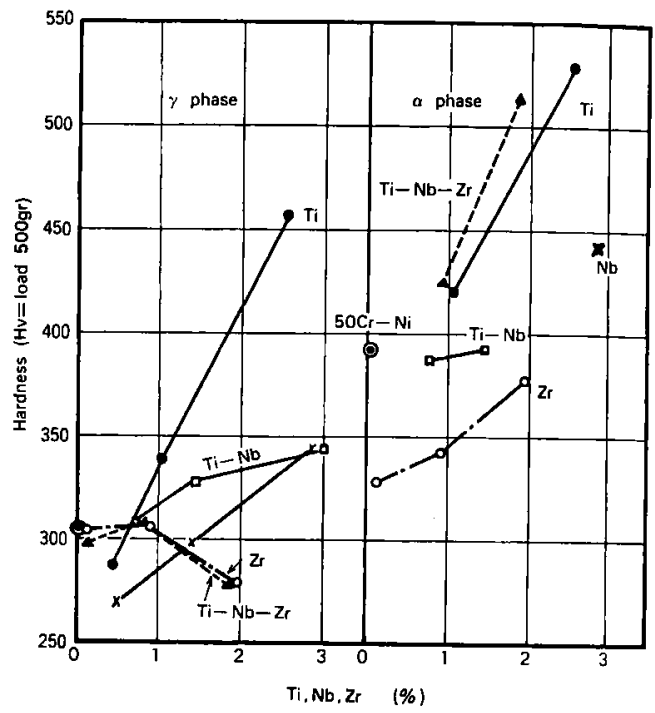

Fig. 11. Effect of alloying elements on the hardness of $\gamma$ and $\alpha$ phace.

\section{3 溶解方法の影栱}

大気溶解材にて $2 \sim 3$ 加工性に及济す諸因子につい て検討したが，さらに真空溶解した場合の影算をみる ベく一部の成分について $5 \mathbf{~ k g}$ 鎙塊を溶解し，実験を行 った。化学成分は Tbale 3 に示す。すなわち

Table 3. Chemical composition of materials made by vacuum induction melted.

\begin{tabular}{r|c|c|c|c|c|c|c|r|r|r|r}
\hline No. & $\mathrm{C}$ & $\mathrm{Si}$ & $\mathrm{Mn}$ & $\mathrm{P}$ & $\mathrm{S}$ & $\mathrm{Ni}$ & $\mathrm{Cr}$ & $\mathrm{Ti}$ & $\mathrm{Nb}$ & $\mathrm{Zr}$ & $\mathrm{RE}$ \\
\hline 1 & 0.074 & 0.25 & 0.34 & 0.005 & 0.008 & 48.53 & 49.33 & - & - & - & - \\
12 & 0.110 & 0.28 & 0.40 & 0.007 & 0.003 & 46.35 & 50.11 & - & 1.45 & - & 0.3 \\
15 & 0.071 & 0.27 & 0.36 & 0.008 & 0.007 & 47.37 & 48.97 & - & - & 1.5 & - \\
24 & 0.110 & 0.28 & 0.33 & 0.010 & 0.009 & 44.91 & 50.28 & 0.46 & 1.49 & 1.5 & 0.3 \\
\hline
\end{tabular}

$50 \mathrm{Cr}-50 \mathrm{Ni}$ 標準材，大気溶解材では加工性の良くなか った Nb-RE 添加材，加工性改善に有効であるが RE 添加の効果の少ないZr材扰よび $\mathrm{Ti}, \mathrm{Nb}, \mathrm{Zr}, \mathrm{RE}$ 複 合添加したものである。

Fig.12は真空溶解材のねじり試験結果で，先の大 気材との比較で示した複合添加材を除きいずれす真空 溶解をすることにより向上する。Fig.13 は真空溶解
材の落重試験結果を示したものであるが，ねじり試験 結果と類似の傾向を示した。襀合添加の場合はTotal 約 $3.5 \%$ 第 3元素を添加しているので, Total 量が 多いためか相互作用によるものかは明らかでないか， 真空，大気のいずれを問わず非常に加工性が覀い。 


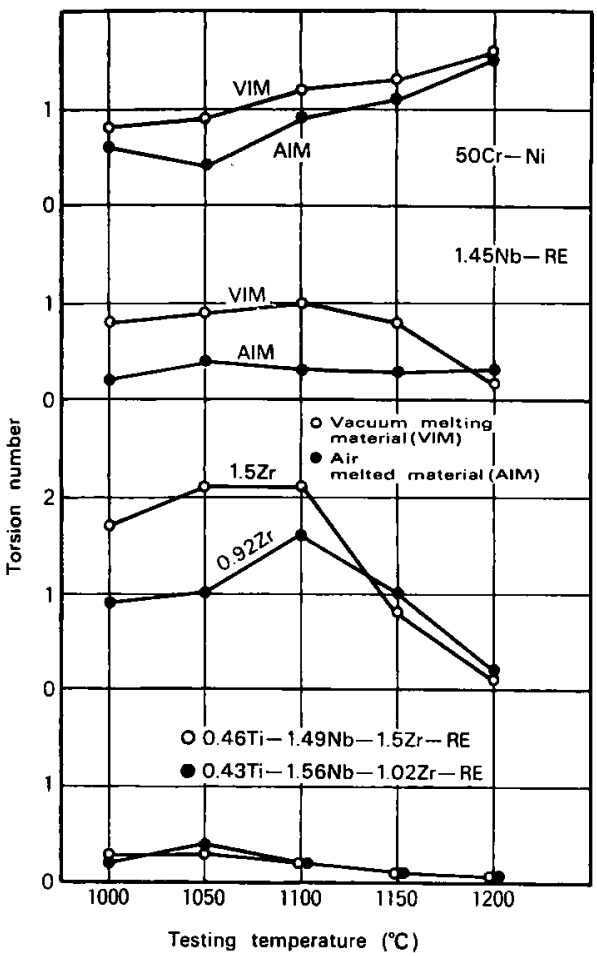

Fig. 12. Comparsion of torsion number of materials made by VIM (Vacuum melted) and AIM(Air melt).

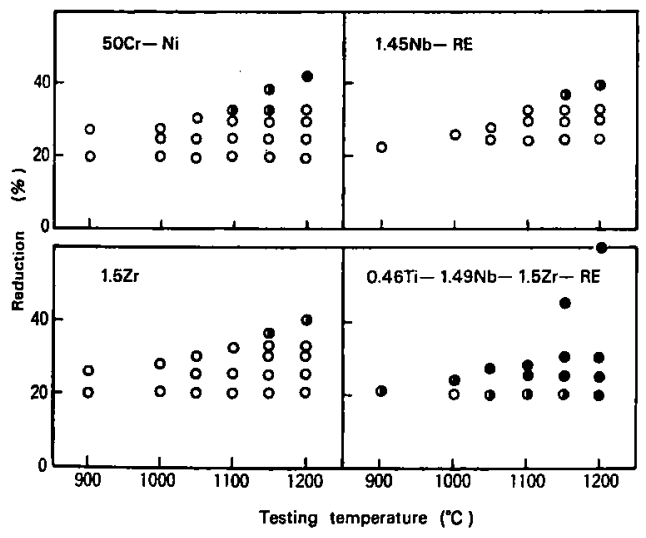

Fig. 13. Effect of alloying elements in upsetting test (VIM).

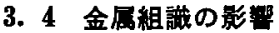

50Cr-Ni 合金の熱間加工が困難な原因は $\alpha+r の 2$ 相合金であり，塑性変形能の低い $\alpha$ 相（高 $\mathrm{Cr}$ 相）に よることが報告されている。2 相合金の場合，その境 界に応力集中が起るためで8)，(1) Zr など Ni を共晶 (Ni $5 \mathrm{Zr}$ ）を形成する元素を添加し，金属化合物によ
り境界の延性を向上する。(口)高 $\mathrm{Cr} \alpha$ 相中の窒素の固 着による脆化の防止を目的に窒素との親和力の強い元 絜を添加するなどの改善措圆がとられている4。 $50 \mathrm{Cr}-50 \mathrm{Ni}$ 合金の凝固組織は冷却速度に依存するが， 本実験鋼塊においては初晶の $\alpha_{1} と \Upsilon_{1}$ ならびに固相変 態により析出した粒界反応型の層状 $\alpha$ 相からなってい

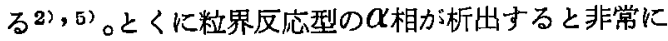
䩲性の低下をきたす。しかし本些験での各種元素を添 加することによりいずれす $\alpha$ 相の析出を㧕制し， $\alpha_{1}$ あ粒状化する。また，Zrおよび Zr を含むTi， Nb の複合添加材では $\alpha$ 相と $\gamma$ 相の境界に Ni との共晶を 形成している。EPMA 分析の結果では，Zrとともに $\mathrm{Ti}, \mathrm{Nb}$ 含まれており，とくにZr単独添加の場合と 比洨し，複合添加材の融点は，熱分析結果から非常に 低下していることかかかかった。さらに複合添加材はそ の量が多くなると $\alpha_{1}$ が極度に粗大化する。Fig. 7〜 9 および Fig. 12 で示した 複合添加材の著しい加工性 の劣化は上記 $\alpha_{1}$ 相の粗大化，共晶の融点の低下など がその原因の一つとして考えられる。

\section{5 鋳造材と銓造材の比較}

鋳造材についてねじりおよび落重試験を行ったが， $\mathrm{Ti}$ や Zr 添加材で加工性改善に效果が認められたし かし，全体にわじり回数が非常に少ない。ステンレス
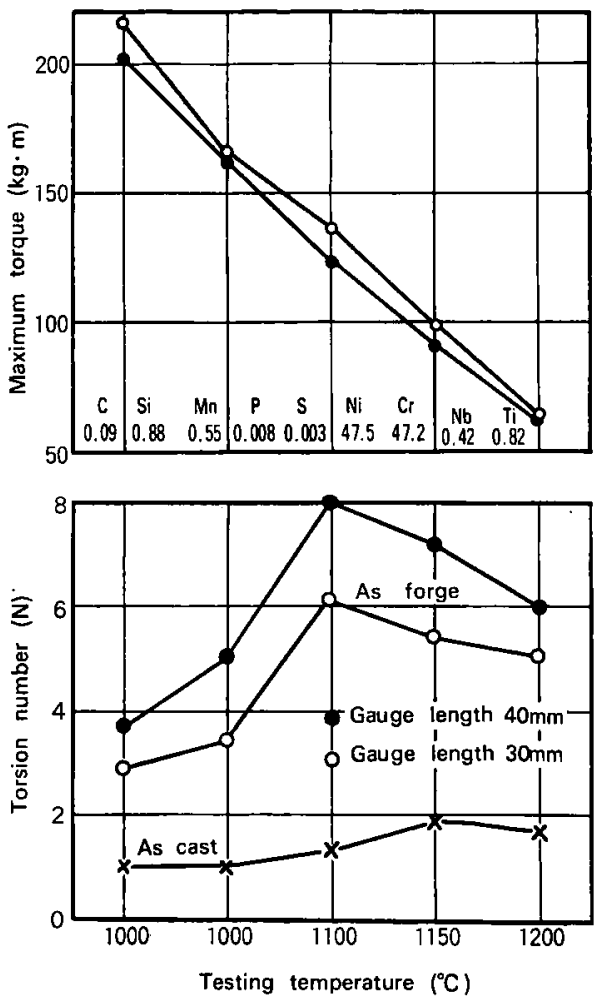

Fig. 14. Results of torsion test on forging material. 
鋼塊においても鍛造材と比較するとかなり少ないね じり回数しか示さないとの報告すあるもことから， Fig.14に示すごとく0.4Nb-0.8 Ti 添加した鍛造材に ついてねじり試験を行った。参考のために類似銅種の 鋳造材の結果をも示したが，鋳造材ではねじり回数 1 〜 2 回のものか鍛造材では $3 \sim 6$ 回と増加した。平行 部 $40 \mathrm{~mm}$ のわのでは最高 8 回と非常にねじり回数が向 上した。これは鉎造による組織の均質化と塊状の $\alpha$ 相 (Cr-rich 相) の微細化によるすのである。したか： って鍛造材を高温で長時間加熱すると $\alpha$ 相がふたたび 塊状になり若干加工性の低下をきたす。

\section{6 添加元素と耐食性との関係}

以上, 熱間加工性に及活す添加元素, その他の要因 について定性的に実験調查を行ったが，加工性改善の ために添加した元素によって基本的な性能の劣化が大 きくあっては好ましくない。

そこでFig.15 に示すごとく各種高温度食試験を行 った結果, これら元素の添加がくに著しく耐食性の 劣化をきたすことがないことが判明した。

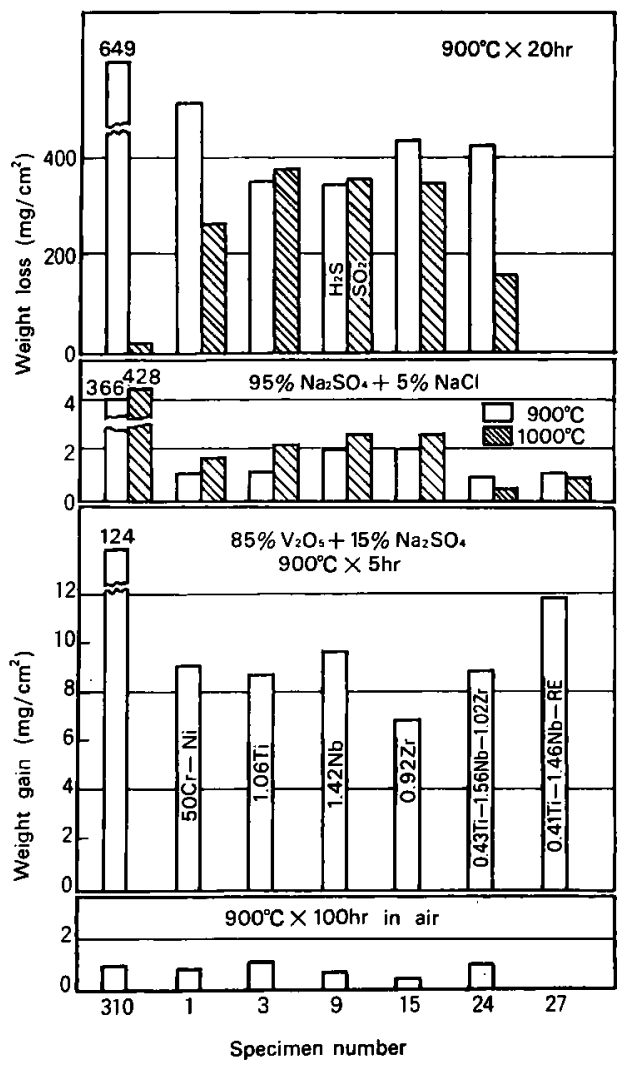

Fig. 15. Results of hot corrosion tests.

\section{4. 結}

50Cr-Ni合金の熱間加工性向上を目的として，諸条 件の影響について実験調查を行った結果, つぎの点が 明らかとなった。

(1) Ti，Zr 扣よび Nb を添加するといずれも $50 \mathrm{Cr}-50 \mathrm{Ni}$ で析出する脆い粒界反応型の $\alpha$ 相の析出 を抑制し， $\alpha_{1}$ を粒状化する。

(2) Ti 扰よび Zr の添加により加工性は向上する か， Zr 量が多くなると $\alpha_{1}$ 相か粗大化し，か党って 劣化する。

(3) $\mathrm{Zr}$ とともに Ti，Nbを複合添加すると Ni との 共晶を作り， $\mathrm{Zr}$ 単独添加材と比較し，その融点を著 しく低下させ，さらに $\alpha_{1}$ 相をより粗大化させるた めにかえって劣化させる。したがって全添加量を考虑 する必要がある。

（4）高 Cr 合金ではとくに窒素が加工性に有害であ るが，真空溶解によりその繁害がかなり除去すること ができ，加工性も改善される。しかし，複合添加材で は効果が認められなかった。

（5）鍛造加工することにより $\alpha_{1}$ 相が微細・均質化 し，加工性は著しく向上する。

したがって，本合金の熱間加工性を向上させるため には，初晶の $\alpha_{1}$ 相を微細・均一に分散させるための 添加元素ならびに溶製方法を検討する必要があろう。

\section{（文献）}

1) INCO : High Cr High Ni Alloys for High Temperature, Corrosion Resistance, (1966)

2) INCO : IN-657 on Improved Alloy to Resist Fuel-ash Corrosion.

3) 耳野, 木村, 服部, 松下 : 学振 123 委員会報 告, 9(1968) 3 ,

4) P. J. parry, et al. : J. of Inst. of Metals, 97 (1969), 373

5）宗, 磯部：学振123委負会報告, 15 (1974) 3 ,

6）加藤, 金井, 阿部：鉄と鋼，46（1960）10, 1268 